\title{
Suriyeli Mülteci Kadınlar ve İnsani Güvenlik
}

\author{
Syrian Refugee Women and Human Security
}

$\ddot{O} z$

Suriye'de iç çatışmanin başladı̆̆ 2011 Mart ayından itibaren milyonlarca Suriyeli, güvenlik, korunma ve siğınma hakk için hem Avrupa'ya, hem de sinır ülkelere göç etmektedir. Kadın, erkek ve çocuk göçmenler zorunlu göçün yarattı̆̆ güvensiz ortamdan, risklerden ve tehlikelerden farkl şekilde etkilenmektedir. Bu nedenle çalışmada, Suriye iç savaşından kaçan mültecilerin yarısını oluşturan ve genellikle göz ardı edilen Suriyeli mülteci kadinların tehdit algısı, insani güvenlik bağlamında ele alınmıştır. Bu kapsamda, Birleşmiş Milletler raporları, sivil toplum örgütlerinin araştırmaları ve uluslararası medyaya yansimalar analiz edilmiştir.

Anahtar Kelimeler: Zorunlu Gö̧,, Uluslararası Güvenlik, Suriyeli Mülteci Kadınlar, Tehdit, İnsani Güvenlik.

\section{Abstract}

Due to the Syrian conflict beginning in March 2011, millions of Syrians have migrated to other countries to seek safety, protection or asylum. This forced migration has caused different vulnerabilities, risks, and insecurity for male, female and child migrants. Therefore, this work evaluates the threat perception of Syrian refugee women, who had to flee from Syrian conflict and who consist of half of the population of the refugees, within the context of human security. In this framework, an in-depth analysis of United Nations reports, researches of non-governmental organizations, and international media coverage have been performed in order to illustrate different threat perceptions of the Syrian refugee women.

Keywords: Forced Migration, International Security, Syrian Refugee Women, Threat, Human Security.

\footnotetext{
*Dr., Jandarma Genel Komutanlığ1, e-posta: ozbah2002@ yahoo.com.

** Dr., Jandarma Genel Komutanlığı, e-posta: eozdemir2002@ gmail.com.
}

Geliş Tarihi/Received: 17.12.2017

Kabul Tarihi/Accepted: 16.04.2018 


\section{4}

Güvenlik Stratejileri

Y11: 14

Say1: 27

\section{Giriş}

Savaş, doğal afet, kıtlık veya işsizlik gibi insanların yaşadıkları yerlerden göç etmesine sebep olabilecek birçok sebep bulunmaktadır. Suriye açısından değerlendirildiğinde, insanların kitleler halinde göç etmesini etkileyen sebebin ülke içinde yaşanan iç savaş olduğu görülmektedir. Çatışma, zorunlu göçün ve bunun sonucu olarak da mültecilerin ortaya çıkmasına neden olmuştur. ${ }^{1}$ Yedinci yılına giren Suriye İç Savaşı, 2011 yılında başladığından itibaren milyonlarca Suriyeli, güvenlik, korunma ve sığınma hakkı için Avrupa'ya ya da diğer ülkelere göç etmiştir. Buna göre, 6,5 milyon Suriyeli ülke içinde; 4,8 milyon Suriyeli ise Türkiye, Lübnan, Ürdün ve Irak gibi komşu ülkelere göç etmiştir. ${ }^{2}$ Avrupa ülkelerinde ise Suriyeli mülteci sayısı 1.120.432'ye ulaşmıştır. ${ }^{3}$ Milyonlarca Suriyelinin hem Avrupa ülkelerine, hem de sınır ülkelere bir anda göç etmesi; siyasi çevrelerin yanı sıra uluslararası aktörlerin de gündemini işgal eden bir konu haline gelmiştir. Kısacası, "Suriye' de yaşanan iç savaş son yirmi yılın en kötü mülteci krizini yaratmıştır".

Kadın, erkek ve çocuk mülteciler zorunlu göçün getirdiği güvensiz ortamdan, risklerden ve tehlikelerden farklı şekilde etkilenmektedir. Gerek sınır ülkelere, gerekse Avrupa ülkelerine göç sırasında Suriyeli kadın mültecilerin karşı karşıya kaldıkları "tehdit"in insani güvenlik

\footnotetext{
${ }^{1}$ Edward Newman, "International Security, and Human Vulnerability: Introduction and Survey", Edward Newman and Joanne van Selm, (ed.), Refugees and Forced Displacement: International Security, Human Vulnerability, and The State, United Nations University Press, New York, 2003, ss. 3-31.

${ }^{2}$ OCHA (United Nations Office for the Coordination of Humanitarian Affairs), "About the Crisis", http://www.unocha.org/syrian-arab-republic/syria-country-profile/aboutcrisis, (Erişim Tarihi: 17. 06. 2016).

${ }^{3}$ UNHCR (United Nations High Commissioner for Refugees), Syria Regional Refugee Response, Office of the United Nations High Commissioner for Refugees, New York, 2016.

${ }^{4}$ UNHCR (United Nations High Commissioner for Refugees), Worldwide Displacement Hits All-Time High as War and Persecution Increase, Office of the United Nations High Commissioner for Refugees, New York, 2015.
} 
bakımından değerlendirilmesi, çalışmanın konusunu oluşturmaktadır. Savaş, çatışma ya da kargaşa ortamında kadınların maruz kaldıkları cinsel ve toplumsal cinsiyet temelli şiddet türleri ve tehdit algıları, bölgelere göre farkl1l1k göstermekte olup; bu durum Suriyeli kadın mülteciler için de geçerlidir. Mülteci kadınların hayatlarını olumsuz yönde etkileyen bu güvenlik tehditlerinin değerlendirilmesi bizi insani güvenlik kavramına yaklaştırmaktadır. İnsani güvenlik, zorunlu göç kavramı ile yakından ilişkilidir. Savaştan, çatışmadan, kıtlıktan veya ülkenin içinde bulunduğu sosyal ve ekonomik problemlerden kaçan göçmenlerin ya da mültecilerin gerek ülkelerinde, gerekse sığınmaya çalıştıkları ülkelerdeki güvenliğe veya tehdit algısına etkilerinin insani güvenlik kavramı içinde değerlendirilmesi gerekmektedir.

Suriyeli mülteci kadınlar, sığınma hakkı talep ettikleri ülkelerde farklı farklı tehditlerle karşılaşmakta ve tehdit algıları bu ülkelerin yaklaşımlarına göre değişiklik göstermektedir. Bu nedenle, mülteci kadınların tehdit ve korku algısının bireysel düzeyde anlaşılması ve gerekli tedbirlerin alınması için toplumsal cinsiyet temelli bir araştırmaya gerek duyulmaktadır. Çalışmada zorunlu göç sonucu çeşitli ülkelere göç eden Suriyeli mülteci kadınların karşılaştıkları ya da algıladıkları "tehdit" analiz edilmiştir. Göç olgusu; kat edilen mesafe, zorunlu ya da gönüllü olması, ekonomik boyutu, sosyolojik ve antropolojik yönü gibi farklı açılardan ele alınan bir kavram olması nedeniyle; uluslararası güvenlik, uluslararası ilişkiler, ekonomi ve sosyoloji gibi farklı alanları da içine alan teorilerle açıklanmaya çalışılmıştır. Bu makalede ağırlıklı olarak uluslararası güvenlik yaklaşımı çerçevesinde bir değerlendirme amaçlanmış olsa da, sınırlı olarak göç teorilerinden de istifade edilecektir. $^{5}$

\footnotetext{
${ }^{5}$ Çalışmaya ışık tutabilecek modern göç teorilerinin başlıcaları; Neo-klasik Göç Teorileri, Göç Sistemleri Teorisi, İlişkiler Ağı Teorisi, Dünya Sistemleri Teorisi, İkiye Bölünmüş Emek Piyasası Teorisi ve Yeni Göç Teorisi olarak sıralanabilir. Çalışmada da değinildiği gibi, değerlendirmenin ana kriterini güvenlik teorileri oluşturmakla beraber, göçün disiplinler arası bir kavram olması dolayısıyla göç teorilerine de sınırlı olarak değinilecektir.
}

Güvenlik Stratejileri

Y11: 14

Say1: 27 
116

Güvenlik

Stratejileri

Y11: 14

Say1: 27

\section{1. İnsani Güvenliğe Uzanan Uluslararası Güvenlik Anlayışı}

Uluslararası güvenlik, uzun süredir akademisyenlerin, siyasetçilerin ve entelektüel çevrenin merkezinde yer alan bir kavram olmuştur. Zamanla bu kavram tanım itibariyle değişikliğe uğrayarak yeni boyutlar kazanmıştır. Tarihsel bir bakış açısıyla değerlendirildiğinde, başlangıçta güvenlik kavramının devletlerin asıl amacının ulusal sınırlarını diğer devletlerin askeri gücünden korumak ve bu doğrultuda önlemler almak üzerine temellendirildiği görülmektedir. $\mathrm{Bu}$ önlemlerin en başında ordunun olabildiğince silahlanması gelmekteydi. Zamanla akademisyenler ve siyasi aktörler, gelişen anlayış çerçevesinde, sadece ulusların değil, bireylerin de ekonomik ve fiziksel olarak güvenliğinin tehdit altında olduğunu düşünmeye başlamıştır. Hatta bu değişen güvenlik anlayışında, devletler bireylerin güvenliğini tehdit eden unsurlardan sadece biri olarak gösterilmeye başlanmıştır. Buna göre, güvenlik tehdidi algılamaları; savaş, çatışma, salgın hastalık, çevre kirliliği, açlık, küresel ısınma, kıtlık, uluslararası kaçakçılık, doğal afetler, nüfus artış1, etnik çatışma, terör ve göç olarak genişlemeye başlamıştır. ${ }^{6}$

Güvenlik alanının genişliği, alanın politik ve akademik çevrelerde farklı tanımlanmasına neden olmaktadır. $\mathrm{Bu}$ nedenle güvenlik alanlarının bütün uygulamalarını ve konularını içine alan ve herkesin fikir birliğine vardığı kapsamlı bir güvenlik tanımı bulunmamaktadır. Uluslararası göç, terör, şiddet, iç savaş ve çatışmalar günümüzde hâlâ, siyasi ve akademik alanların yanı sıra, medyada da tartışılmaya devam edilirken; şu sorular doğal olarak akla gelmektedir: "Güvenliğin anlamı nedir?", "Kimin güvenliği?", "Güvenlik nasıl inşa edilmektedir?"

Klasik realizmin güvenlik tanımına göre, gücü elde etmek için devletler de tıpkı insanların çıkarcı ve bencil doğası gibi hareket etmektedir. İnsanların bu davranışları onların güce olan arzularını

${ }^{6}$ Barry Buzan, People, States and Fear: The National Security Problem in International Relations, Harvester Books, Chapel Hill, University of North Carolina Press, Brighton, 1983, ss. 214-242; Pauline Kerr, "Human Security", Alan Collins, (ed.), Contemporary Security Studies, Oxford University Press, Oxford, 2013, ss. 104-117. 
pekiştirmekte ve bu da savaşların sebeplerini açıklamaktadır. Devletleri yöneten firsatçı politikacılar agresif yapılarından ve daha fazla güç elde etmek amaciyla uluslararası alanda yayılmacı bir politika izleyebilmektedir. ${ }^{7} \mathrm{Bu}$ anlamda, klasik realizm, devlet merkezli bir Güvenlik Stratejileri anlayış öne sürmekte ve uluslararası sistemi devletlerarası ilişkileri düzenleyen anarşik bir ortam olarak görmektedir.

Kuramın ilişkileri düzenleyen temel mekanizması, askerî caydırıcılık ve müttefik devletlerin kontrolüdür. Güvenliği yukarıdan aşağıya bir bakış açısıyla ele almakta ve en önemli unsur olarak gücü görmektedir. ${ }^{8}$ Askerî gücün yanında coğrafya, nüfus, doğal kaynaklar ve jeopolitik konum; ulus devletlerin güvenliğini korumak için sahip olması gereken temel güç unsurlarıdır. Realist güvenlik anlayışına göre; içinde bulunulan çatışma ve rekabet ortamında, devletler, sınır güvenliklerini koruyabilmek için güç potansiyellerine sahip olmak zorundadır. Ulus-devlet anlayışı, bencil ve çıkarcı bir yapıya sahiptir. ${ }^{9}$

Kenneth Waltz'ın Uluslararası Politikalar Kuramı başlıklı çalışması realist bakış açısına önemli katkılar sağlamıştır. Çalışma, sistemlerin yapı üzerine odaklandığından ve birbirleriyle etkileşim içerisinde olduğundan bahsetmektedir. ${ }^{10}$ Buradaki yapı, uluslararası ilişkileri düzenleyen ve sadece devletlerden oluşan sistem olarak tanımlanmaktadır. Neorealizm, bu nedenle devlet içi politikaya değil; daha çok devletler arasındaki ilişkiye odaklanmakta; çok uluslu şirketlerin ve uluslararası aktörlerin bağımsız hareket etmedikleri için yapı içerisinde yer almadıklarını düşünmektedir. Devletler açısından ise, önemli olan, güce sahip olmaktır. Neorealizm, klasik realizmden

\footnotetext{
${ }^{7}$ Colin Elman, "Realism”, Paul D. Williams, (ed.), Security Studies, Routledge, New York, 2008, s. 17.

8 Tarak Barkawi ve Mark Laffey, "The postcolonial moment in security studies", Review of International Studies, 2006, no. 32(2), ss. 329-352.

${ }^{9}$ Terry Terriff, Security Studies Today, Polity Press, Cambridge, 1999, s. 32; James E. Dougherty ve Robert L. Pfaltzgraff, Jr., Contending Theories of International Relations, New York, Longman, 2001, ss. 93-95.

${ }^{10}$ Kenneth Waltz, Theory of International Politics, Addison Wesley, Reading, MA, 1979.
} 
118

Güvenlik Stratejileri

Y11: 14

Say1: 27

bu noktada ayrılmaktadır. Neorealizmde, güç, amaç değil; sadece devletlerin uluslararası sistemde var olabilmek için kullandıkları bir araçtır. Bu güç, uluslararası ilişkilerin anarşik yapısından kaynaklanmakta olup; bu anlamda birbiriyle bağlant1lı askerî, ekonomik, kültürel ve politik mekanizmaların bir arada değerlendirilmesini gerektirmektedir. ${ }^{11}$ Ancak askerî güç, devletin güvenliği açısından son derece önemli olduğu için, "yüksek politika"; diğer unsurlar ise "alçak politika" bağlamında ele alınmıştır.

Neoliberallere göreyse, karşılıklı ekonomik bağımlılık, devletlerin gücünü belirlemektedir. Diğer taraftan, sivil toplum örgütleri, teknoloji ve eğitim gibi diğer etkenler de uluslararası ilişkiler alanı için önemlidir. Bu nedenle rasyonel davranan devletler, uluslararası alanda "karşılıklı bağımlılık" ilkesiyle iş birliğine gitmektedir. ${ }^{12} \mathrm{Bu}$ anlayış, yapısalcılık kuramıyla yakından ilişkilidir. Sosyoloji ve eleştirel kuramların birleşimi olan yapısalcılık, dünyanın sosyal bir şekilde etkileşim sonucu oluştuğunu varsaymaktadır. $\mathrm{Bu}$ kurama göre, kurumlar ve yapılar karşılıklı olarak birbiriyle etkileşim içerisindedir. $\mathrm{Bu}$ nedenle normlar, kimlik ve fikirler gibi düşünsel faktörler dünya politikasının oluşmasında merkezî yerdedir. Bütün bu unsurlar, güvenliğe etki etmektedir; çünkü güvenlik de sadece askerî güç ile açıklanmayacak kadar tarihsel ve kapsamlı bir süreci ifade etmektedir. Yapısalcılara göre, bu süreçte güvenlik sosyal bir inşadır. ${ }^{13}$ Örneğin; kimlik, norm, değerler ya da kültür; devletlerin askerî alanda verdikleri kararlar1 etkilemektedir. ${ }^{14}$ Burada güvenlik belli bir grubun temel değerlerini korumak olarak anlaşılabilir. Fakat bu sefer de şu sorular

${ }^{11}$ Kenneth Waltz, "Political Structures", Robert O. Keohane, (ed.), Neorealism and its Critics, Colombia University Press, NY, 1986.

12 Joseph Nye, "The Changing Nature of World Power," Political Science Quarterly, 1990, 105/2, ss. 177-192.

${ }^{13}$ Matt McDonald, "Constructivism", Paul D. Williams, (ed.), Security Studies: An Introduction, Routledge, New York, 2008, ss. 59-72.

${ }^{14}$ Peter Katzenstein (ed.), The Culture of National Security: Norms and Identity in World Politics, Columbia University Press, New York, 1996), ss. 1-32; Matt McDonald, 2008, age, ss. 60-61. 
ortaya çıkabilir: "Kim bu grup?", "Bu grubun temel değerleri ne?", "Bu temel değerlere tehdit nereden gelmektedir?", "Bu değerler nasıl korunmalıdır?" Yapısalcıların bütün bu sorulara verdikleri cevap, güvenliğin tarihsel ve sosyal bağlamda, sosyal etkileşim aracıllğıyla uzun süren tartışmalar sonucu oluştuğudur. ${ }^{15}$ Yapisalcılar, bu nedenle, keskin ve bütün ulusları kapsayan güvenlik tanımı yapmaktan kaçınmaktadır.

Kopenhag Okulu, yapısalcı gelenek içerisinde, güvenlik çalışmalarına getirdiği yeni yaklaşımlar dolayısıyla önemli bir yere sahiptir. Okul'un önde gelen isimleri Buzan, Wæver ve Wilde, güvenlik kavramının anlamını çevresel faktörleri, yoksulluğu ve insan haklarını da kapsayacak şekilde genişletmiştir. Okul, yapısalcı gelenek içerisinde, belirli aktörlerin "söz eylem"ine (speech act) göre güvenliğin temellendiğinden bahsetmektedir. ${ }^{16}$ Wæver ve Buzan güvenliğin merkezini "sektörler", "bölgesel güvenlik kompleksleri” ve "güvenlikleştirme" kavramlarıyla açıklamıştır. Yazarlara göre, askerî, siyasi, ekonomik, toplumsal ve çevresel sektörler belirli güvenlik alanlarının birbirleriyle etkileşim içerisinde olduğu yerleri kapsamaktadır. "Bölgesel güvenlik kompleksleri"nde, coğrafi ayrımlar, kendi güvenlikleri için birbirleriyle etkileşim içerinde olmalıdır. ${ }^{17}$

"Güvenlikleştirme" kavramı da bu Okulun dile getirdiği önemli kavramlardandır. Kavram, "tehdit"in siyasi elitler tarafindan söylemsel inşasıyla ilgilenmektedir. Siyasi elitlerin söz eylemleri belirli konuları tehdit unsuru olarak görüp güvenlik kapsamı içine alırken; diğer konuları tehdit olarak algılamayarak güvenlik kapsamı içinde değerlendirmemektedir. ${ }^{18}$ Ancak Okul, politize edilmiş ve politize edilmemiş güvenlik kavramlarına karşıdır. Politize edilmemiş konular,

\footnotetext{
${ }^{15}$ Matt McDonald, "Human security and the construction of security", Global Society, 2002, 16(3), ss. 277-295.

${ }^{16}$ Matt McDonald, 2008, agm, ss. 59-60.

${ }^{17}$ Barry Buzan, Wæver Ole ve Wilde de Jaap, Security: A New Framework for Analysis, Lynne Rienner Publishers, Boulder, 1998, s. 25.

${ }^{18}$ Ole Wæver, "Securitization and Desecuritization", Ronnie D. Lipschutz, (ed.), On Security, Columbia UP., New York, 1995, ss. 46-86.
}

Güvenlik Stratejileri

Y11: 14

Say1: 27 
120

Güvenlik Stratejileri

Y11: 14

Say1: 27

devletin üzerinde durmadığı konuları kapsarken; politize edilmiş konular, devletin tartıştığı ve gündemine aldığ konuları kapsamaktadır. Güvenlikleştirme ise her iki konudan farklı olarak tehdit konularını ortaya koymakta ve güvenlik önlemlerini tartışmaktadır. ${ }^{19}$

Güvenlikle ilgili tartışmalar devam ederken, konu ile ilgili önemli bir gelişme 1994 yılında Kanada'nın York Üniversitesi'nde ortaya atılmıştır. Özellikle Ken Booth'un "Security and Emancipation" başlıklı makalesi, farklı bir eleştirel güvenlik yaklaşımının Galler Okulu'nun (Welsh School) doğmasına neden olmuştur. ${ }^{20}$ Makalede, insanların özgür olabilmeleri için yapmak istedikleri şeylerin önünde herhangi bir engelin olmaması gerektiği vurgulanmıştır. Örneğin savaş, çatışma, yoksulluk, açlık, kıtlık, çevre kirliliği ya da doğal afetler gibi her türlü tehdit, insanların yapmak istediği şeyleri sınırlamaktadır. ${ }^{21}$ Hatta bu yaklaşım, tehdide yönelik toplumsal cinsiyet deneyimlerine vurgu yapan güvenlik politikaları hakkında farklı bakış açıları da ortaya koymuştur. ${ }^{22}$ Galler Okulu akademisyenleri öncelikle güvenliğin ve güvensiz ortamın altını çizmiştir. ${ }^{23}$ Okulun temsilcilerinden Booth, Krause ve Williams, güvenlik çalışmalarında güvenliğe sadece devlet açısından bakmaktan kaçınılması gerektiğini vurgulamıştır. ${ }^{24}$ Booth, ${ }^{25}$ insanlara karşı oluşan tehdidin dolaylı veya dolaysız olarak devletten geldiğini belirtmiştir. Yazara göre, güvenlik kavramının bireylerin bakış açısından analiz edilmesi gerekmektedir. $\mathrm{Bu}$ nedenle, bireyin

${ }^{19}$ Barry Buzan, Ole Wæver ve Jaap de Wilde, age, s. 25.

${ }^{20}$ Pınar Bilgin, "Critical Theory, Security Studies: An Introduction", Paul D. Williams, (ed.), Security Studies, Routledge, New York, 2008, s. 92.

${ }^{21}$ Ken Booth, "Security and Emancipation", Review of International Studies, 17, 1991.

${ }^{22}$ Hayward Alker, "Emancipation in the critical security studies project", C. Hacke, G.K. Kindermann and K.M. Schellhorn, (ed.), The Heritage, Challenge, and Future of Realism, Bonn University Press, Göttingen, 2005, s. 195.

${ }^{23}$ Ken Booth, Theory of World Security, Cambridge: Cambridge University Press, 2007, s. 98.

${ }^{24}$ Ken Booth, 1991, age, ss. 313-326; Keith Krause ve Michael Williams, Critical Security Studies: Concepts and Cases, UCL Press, London, 1997.

${ }^{25}$ Ken Booth, 1991, age, ss. 313-326. 
özgürleşmesi Galler Okulu'nun merkezinde yer almaktadır. ${ }^{26}$

Bu noktada, Everett Lee tarafindan 1966 yılinda ortaya konan İtme-Çekme Teorisi'nin göç hareketlerini açıklamanın yanında özgürleşme kavramını da destekler nitelikte olduğu söylenebilir. Lee'ye göre, göçü etkileyen başlıca dört faktör (1) kaynak ülkeden kaynaklanan olumsuz olduğu değerlendirilen şartlar, (2) göç edilecek ülkenin sağladığ 1 imkânlar, (3) engeller ve (4) kişisel sebepler olarak sıralanmaktadır. ${ }^{27}$ Kaynak ülkede yaşanan olumsuz faktörler, şahısları ülkeden ayrılmaya yönlendirirken; hedef ülkedeki olumlu koşullar, teşvik edici bir özellik arz etmektedir. Bu anlamda kişinin kendini tahdit altında hissettiği şartların yaşandığı kaynak ülkeden kendini daha güvende hissedeceğini düşündügü hedef ülkeye göç etmesi de benzer şekilde değerlendirilebilir.

1990'lı yıllardan itibaren devletler arasındaki çatışmalar, sadece ulusal güvenliği tehdit eden bir unsur olarak değil; aynı zamanda insanların güvenliğini tehdit eden bir unsur olarak da algılanmaya başlanmıştır. $^{28}$ Böylece insani güvenlik kavramı, bütün insanları kapsayan bir politika olarak gündeme gelmiştir. İnsani güvenlik, insanları, savaş, çatışma ve soykırımdan korunması gerekenler olarak uluslararası hukuk kapsamında değerlendirmektedir. Güvenlik sınıflandırması olarak ekonomi, gıda, sağlık, çevre, kişisel, toplum ve politikayı kapsam içine almıştır. Nüfus artışı, uyuşturucu kaçakçılığı ve uluslararası terör, tehdit olarak değerlendirilmektedir. ${ }^{29}$

İnsani güvenlik kavramı, uluslararası güvenlik çalışmalarında akademik bir çalışma alanı olmasının yanında, politika alanında da

\footnotetext{
${ }^{26}$ David Baldwin, "The Concept of Security", Review of International Studies, 1997, 23, s. 10.

${ }^{27}$ Everett S. Lee, “A Theory of Migration”, Demography, 1966, vol. 3, no. 1, s. 50.

${ }^{28}$ Ken Booth, 1991, age, ss. 62-66.

29 UNHDP (United Nations Human Development Programme), United Nations Human Development Report, Oxford University Press, New York, 1994; Ken Booth, Theory of World Security, Cambridge University Press, Cambridge, 2007, s. 321.
}

Güvenlik Stratejileri

Y11: 14

Say1: 27 
122

Güvenlik Stratejileri

Y1l: 14

Say1: 27

önemli gelişmeler kaydetmiştir. ${ }^{30}$ Örneğin, savaş, çatışma ve soykırımı önlemek için uluslararası hukukun tüm insanları kapsaması gerekmektedir. Bu kapsamda; ${ }^{31}$

İnsani güvenlik zengin ve fakir uluslardaki insanların hepsini kapsamaktadır. Güvenliklerine karşı fakir ülkelerde tehdit, açlık ve hastalığı kapsarken zengin ülkelerde uyuşturucu kaçakçılığ 1 ve suçu kapsamaktadır. Bu tehditlerin hepsi gerçek ve giderek büyümekte ve çeşitlenmektedir. Özellikle bazı tehdit çeşitleri iş güvensizliği ve çevresel faktörler gibi bütün uluslarda yaygındır.

Tehdit algıs1, bireylerin yaşadıkları deneyim ve hissettikleri korku açısından değişiklik göstermektedir. Bu sebeplerden dolayı, insani güvenlik, bireylerin özgürlügünün korunması için temel teşkil etmektedir. İnsanların özgürlüğünün ve mutluluğunun önemini insani güvenlik bağlamında vurgulamıştır. Buna göre; ${ }^{32}$

İnsani güvenlik bütün insanların özgürlügünü güvence altına almak için insanların hayatlarını korumak anlamına gelmektedir. İnsani güvenlik hayatın temelini oluşturan özgürlüklerin korunmasıdır. İnsanları tehditten korumaktır. Bu nedenle insanların ayakta kalmalarını ve nefes almalarını sağlayan süreci inşa etmesi gerekmektedir. Bunun anlamı, kısaca, insanların hayatta kalma, yaşam ve haysiyetini güvence altına alan politik, sosyal, çevresel, ekonomik, askeri ve kültürel sistemlerin oluşturulmasıdır.

Diğer taraftan, küresel dünyada, bireylerin korkuları ve endişeleri sınırsız ve çeşitlidir. Sadece devletler arasında değil, devletlerin içinde de terör saldırıları, etnik çatışma, şiddet, savaş, kargaşa, hastalık ve ani

${ }^{30}$ Columba Peoples ve Nick Vaughan-Williams, Critical Security Studies, Routledge, New York, 2010, s. 121.

31 UNHDP (United Nations Human Development Programme), United Nations Human Development Report, Oxford University Press, New York, 1994.

${ }^{32}$ United Nations Report of the Commission on Human Security, Human Security Now: Protecting and Empowering People, UN, New York, 2003. 
ekonomik dalgalanmalar olmaktadır. $\mathrm{Bu}$ nedenle, insani güvenlik 123 bireyin temel özgürlügünün korunması ile doğrudan ilgilidir. İnsani güvenliğin dar ve geniş anlamı "freedom from fear and freedom from want" olarak yer almaktadır. Korkulardan özgürlük kavramı aslında insani güvenliğin dar anlamında kullanılmaktadır. Genel olarak, siyasi baskıdan ve şiddetten koruma olarak anlaşılmaktadır. ${ }^{33}$ İnsani güvenlik kavramı bireylerin mutlu bir yaşamı ve özgürlüğ̈̈ olarak tanımlanmaktadır. ${ }^{34}$

İnsani güvenliğin temel amacı bireylerin özgürlüğünü korumaya yöneliktir. Özgürlük hayatın özünü oluşturmaktadır. Bunun anlamı bireylerin tüm tehdit ve olası tehditlerden korunmasıdır. Bunun anlamı insanların dayanma gücünü ve nefes almasını sağlayan süreci inşa etmektir. İnsanların yaşamlarını sürdürecek ve saygınlığını artıracak siyasi, sosyal, çevresel, ekonomik, askerî ve kültürel sistemin yaratılmasının sağlanması gerekmektedir.

Güvenliğe ilişkin insan merkezli bu tanıma göre, zorunlu olarak göç eden mülteciler korunması gereken savunmasız gruplar olarak değerlendirilmektedir; çünkü mülteci durumuna düşen insanlar göç sırasında şiddet olaylarıyla karşı karşıya kalmaktadır. Mülteciler üzerinde yapılan araştırmalara göre, göç insan güvenliğine bir tehdit unsuru olarak değerlendirilmektedir. ${ }^{35}$ Örneğin, son beş yılda Suriyeli mülteciler hem Avrupa ülkeleri, hem de sınır ülkeler açısından en büyük mülteci problemi olarak görülmektedir. Hatta mültecileri bazı devletler sınır güvenliği açısından bir tehdit olarak algılamakta;

${ }^{33}$ United Nations Report of the Commission on Human Security, Human Security Now: Protecting and Empowering People, UN, New York, 2003; Columba Peoples ve Nick Vaughan-Williams, Critical Security Studies, Routledge, New York, 2010, s. 126.

${ }^{34}$ United Nations Report of the Commission on Human Security, Human Security Now: Protecting and Empowering People, UN, New York, 2003.

${ }^{35}$ Edward Newman, age; Jane Freedman, "Engendering Security at the Borders of Europe: Women Migrants and the Mediterranean Crisis" Journal of Refugee Studies, 2016, ss. 115; Nana Poku, K. ve Graham David, Migration, Globalisation and Human Security Routledge, London, 2000. 
124

Güvenlik Stratejileri

Y11: 14

Say1: 27

bazıları ise korunmaya muhtaç insanlar olarak görmektedir. Türkiye, Lübnan, Ürdün, Irak ve Misır binlerce Suriyeli mülteciye kapılarını açan ilk ülkeler olmuştur. Almanya, İtalya, Yunanistan, ABD, İsveç, Avustralya, Fransa ve İngiltere gibi ülkeler de sığınmacılara kapılarını açan ülkeler arasında yer almıştır.

Ancak Macaristan, Makedonya, Sirbistan, Slovenya ve Hırvatistan Suriyeli mültecileri sınırlarına tehdit olarak algılamıştır. Macaristan hükümeti, mülteci girişini engellemek için sınırlarına tel örgü çekerek binlerce asker ve polisi buraya yığmıştır. Slovenya da sınırlarında benzer tedbirler almış; mültecilerin sınırlarını kullanarak Batı Avrupa'ya gidişini engellemek için Balkanlara uzanan sınırını kapatmıștır. ${ }^{36}$ Oysa "Mültecilerin Hukuki Statüsüne İlişkin Sözleşme"de "bütün devletlerin, mülteci sorununun toplumsal ve insani yönlerini kabul ederek, bu sorunun devletler arasında bir gerginlik sebebi halini almasını önlemek için olanakları ölçüsünde ellerinden geleni yapmalarını arzuladığını ifade etmektedir" ibaresi yer almaktadır. ${ }^{37}$ Görüldüğ̈ gibi, bütün devletler mülteci sorununa aynı şekilde bakmamaktadır. Kısacası, milyonlarca Suriyeli mültecinin bir anda başka ülkelere göç etmesi ve sığınma talepleri, dünya siyasetinin gündeminin de değişmesine neden olmuştur.

Güvenlik arayışının ötesinde, Suriyeli göçmenlerin hareketliliklerini etkileyen diğer önemli faktörler; ekonomik kazanç, refah ve sosyal imkânlar olarak sıralanabilir. Güvenlik kaygısıyla, ilk ve en yakın durak olan komşu ülkelere geçiş sağlandıktan sonra, imkânlar bakımından daha iyi durumda olan Batı ülkelerine geçiş firsatları aranmaktadır. $\mathrm{Bu}$ anlamda, göç hareketlerini açıklamaya çalışan kuramlardan Merkez-Çevre Kuramı önemli bir açıklama getirmektedir. Kökenleri Wallerstein'ın bağımlılık ve çevre-merkez

${ }^{36}$ Patrick Strickland, "Refugee crisis: Hungary sends more troops to border" Aljazeera, http://www.aljazeera.com/news/2016/03/refugee-crisis-hungary-sends-troops-border 160309134453267.html, (Erișim Tarihi: 10.03.2016).

${ }^{37}$ BMMYK (Birleşmiş Milletler Mülteciler Yüksek Komiserliği), Mültecilerin Hukuki Statüsüne İlişkin Sözleşme, Birleşmiş Milletler Mülteciler Yüksek Komiserliği, 2016. 
kavramlarını barındıran dünya sistemi kuramına dayanan bu kuram; küreselleşme sürecinde sermaye, piyasa, üretim ilişkileri ve teknoloji gibi kavramlar bakımından üstünlük sağlayan merkez ülkelerin, bu bakımlardan zayıf konumda bulunan çevre ülkelerden iş gücü ve göç hareketlerine maruz kaldıklarını savunmaktadır. ${ }^{38}$ Dolayısıyla, bu kuram Suriyeli mültecilerin geniş anlamda güvenlik ihtiyaçlarını karşılamak amacıyla öncelikle komşu ülkelere geçişlerini ve akabinde Batılı ülkelere yönelmelerini açıklamaya yardımcı olmaktadır. Bunun ötesinde, göç alan ülkelerin de mültecileri kabul etmelerinde önemli rol oynayan faktörlerin de anlaşılmasını sağlamaktadır. Bu anlamda; iş gücü ihtiyacı, ülkenin ekonomik durumu, mültecilerin getireceği sosyal ve ekonomik külfet; çevre ülkelerin davranışlarını belirlemedeki önemli kriterler olarak belirmektedir.

Görüldüğü üzere, güvenlik algısı zaman içerisinde belirli sınırlar içinde yaşayan toplumları diğer saldırgan toplumlardan gelen tehdit ve riskleri bertaraf etmek ve korumak üzerine temellendirilen devlet temelli anlayışın ötesinde, bireylerin kendilerine yönelen ekonomik siyasal ve fiziki farkl1 tehditlere karşı kendilerini güvende hissetmelerinin önemini vurgulayan bir anlayışa evrilmektedir. $\mathrm{Bu}$ anlamda göç, hem bireylere yönelik tehditlerden uzaklaşmanın bir aracı, hem de başlı başına bireylerin yaşam şartlarına yönelik bir belirsizlik ve tehdit olarak ortaya çıkmaktadır. Devletlerin kendilerine yönelik bir tehdit olarak algıladıkları Suriyeli göçmen hareketleri, klasik güvenlik yaklaşımının ötesinde birey merkezli bir yaklaşımla da ele alınmalıdır. Çok yönlü bir kavram olması nedeniyle farklı disiplinler ve kuramlarla konuya yaklaşılabileceğinin altını bir kez daha çizilerek bu çalışmanın bakış açısının insani güvenlik ve toplumsal cinsiyet yaklaşımı olduğunu vurgulamakta fayda vardır.

${ }^{38}$ Immanuel Wallerstein, The Modern World-System: Capitalist Agriculture and the Origins of European World-Economy in the Sixteenth Century, Academic Press, New York, 1974. 
126

Güvenlik

Stratejileri

Y11: 14

Say1: 27

\section{2. İnsani Güvenlik Bağlamında Suriyeli Mülteci Kadınlar}

Geleneksel devlet merkezli güvenlik çalışmaları, zorunlu göçü çatışma, terörizm, askerî güç ve devlet ile ilişkilendirmiştir. Zorunlu göç tıpk1 askerî tehditler gibi devletin güvenliğini tehdit eden bir unsur olarak algılanmaktadır. Son on yılın en büyük sorunu haline gelen Suriyeli mültecilerin göç ettiği ülke siyasetine bakıldığında; gerek politikacıların söylemleri, gerekse ülkelerin aldıkları önlemler genellikle mültecileri bir tehdit unsuru olarak görmelerinden kaynaklanmaktadır. Oysa insani güvenlik açısından değerlendirildiğinde; gerek çatışmalardan, gerekse zorunlu göç sırasında ve sonrasındaki güvensiz ortamlardan en fazla etkilenenlerin Suriyeli mülteciler olduğu görülmektedir. Ancak kadınlar, çatışmalardan ve zorunlu göçten farklı şekilde etkilenmektedir. $\mathrm{Bu}$ nedenle, her bir mülteci kadının tehdit alg1s1 ve deneyimi birbirinden farklı olduğundan, aşağıdan yukarıya yaklaşım ve mikro seviye bakış açısının gerekliliği ortaya çıkmaktadır. ${ }^{39}$ Her bir mülteci kadının bireysel olarak değerlendirilmesi, aynı zamanda onların tehdit karşısında korunması, uluslararası güvenlik kapsamında insani güvenlik kavramının daha da anlamlı olmasına neden olacaktır; çünkü insani güvenlik, belirtildiği üzere, insanların hayati özgürlüklerinin korunması ile yakından ilişkili bir kavramdır. ${ }^{40}$

Zorunlu olarak göç eden kadınlar göç sırasında güvenli bir ortam olmayışı nedeniyle, -genel güvenlik kaygılarının ötesinde- cinsel ve toplumsal cinsiyet temelli şiddet olaylarına maruz kalmaktadır. ${ }^{41}$ Kadınların savunmasız ve korunmasız durumlarından faydalanarak şiddet kullananlar arasında polisler, sınır güvenliğini sağlayanlar, siviller, diğer

${ }^{39}$ Ann J. Tickner, Gender in International Relations: Feminist Perspectives on Achieving International Security, Colombia University Press, New York, 1992.

${ }^{40}$ United Nations Report of the Commission on Human Security, Human Security Now: Protecting and Empowering People, UN, New York, 2003.

41 BMMYK'ye (UNHCR 2003) göre cinsel ve toplumsal cinsiyet temelli şiddet sınıflandırılması cinsel şiddet (tecavüz, cinsel istismar, fuhuşa zorlama, cinsel taciz), fiziksel şiddet (taciz, kadın ticareti), duygusal ve psikolojik şiddet (aşağılama), zararlı geleneksel uygulamalar (erken evlilik, zorla evlendirme, namus cinayeti ve kız çocuklarını okula göndermeme) ş̧eklindedir. 
erkek mülteciler ya da mülteci kamplarında görevli sivil toplum 127 kuruluşu çalışanları bulunmaktadır. ${ }^{42}$ Bu zor şartlar altında, kadınların zorunlu göç sırasında ve sonrasında uğradıkları, gördükleri, tanık oldukları şiddet ve tehdit olayları, uluslararası güvenlik çalışmaları açısından son derece önemli bir yere sahiptir. Bu nedenle, kadın mültecilerin tehdit algısının zorunlu göç sırasında ve sonrasında araştırılması, göç sürecinde ortaya çıkan olumsuz etkilerin önlenmesi ve ortadan kaldırılması bakımından toplumsal cinsiyet kavramı bakış açısından uluslararası güvenlik çalışmaları içinde değerlendirilmesi büyük önem arz etmektedir.

Toplumsal cinsiyet bakış açısına sahip yazarların hemfikir olduğu nokta; savaş, çatışma ya da zorunlu göç sırasında kadınların algıladıkları tehdit konusunda, uluslararası güvenlik alanında çok fazla yoğunlaşılmadığı, bunun en büyük sebebinin de bu alanın erkek bakış açisıyla yönetilmesinden kaynaklanmakta olduğudur. ${ }^{43}$ Enloe'nun da belirttiği gibi, uluslararası ilişkiler ve güvenlik alanı, eril karakteri baskın bir yapıya sahip olduğu için, kadınlar güvenlik çalışmalarında marjinalleştirilmiştir. ${ }^{44} \mathrm{Bu}$ yaklaşım, güvenlik çalışmalarının toplumsal cinsiyet eşitsizliğinden ayrı olarak düşünülmemesi gerektiğinin altını çizmektedir. Ulusal ve uluslararası alanda eril tarafindan ekonomik ve politik olarak alınan kararlar, ataerkil yapıyı güçlendirmekte ve toplumsal cinsiyet eşitsizliğini arttırmaktadır. ${ }^{45}$ Kadınlar, güvenlik alanında karar vericiler değil de, daha çok mağdur ya da korunmaya muhtaç grup olarak tanımlanmaktadır. Uluslararası aktörler tarafindan kadınların mağdur olmadan önceki korku ve algıları konusunda çok fazla araştırma bulunmamaktadır. Yapılan araştırmalar, genellikle kadınlar

42 Josie Ensor, "Women in Syria 'forced to exchange sexual favours' for UN aid", The Telegraph, https://www.telegraph.co.uk/news/2018/02/27/women-syria-forced-exchangesexual-favours-un-aid/ (Erişim Tarihi: 24.03.2018).

${ }^{43}$ Caroline Kennedy, "Gender and Security", Alan Collins, (ed.), Contemporary Security Studies, Oxford University Press, Oxford, 2013, ss. 118-130.

${ }^{44}$ Cynthia Enloe, Bananas, Beaches and Bases: Making Feminist Sense of International Politics, University of California Press, Berkeley CA, 1989.

${ }^{45}$ Columba Peoples ve Nick Vaughan-Williams, age, s. 36.

Güvenlik Stratejileri

Y11: 14

Say1: 27 
128

Güvenlik Stratejileri

Y11: 14

Say1: 27

mağdur olduktan sonraki süreçle ilgilenmektedir. Örneğin, kadına karş1 cinsel ve toplumsal cinsiyet temelli şiddetin, ilk kez 31 Ekim 2000 tarihinde 1325 sayılı BM kararı ile savaş suçu kapsamına alınması, 1990 'l y yllarda yaşanan olaylara dayanmaktadır. ${ }^{46}$

1992 y1lından itibaren, üç y1l boyunca, 13.000 ilâ 50.000 arasında Bosnalı Müslüman kadın, Sırp ordusu tarafindan etnik temizlik amaçlı tecavüze uğramış ve işkence görmüştür. Çoğunluğu Sırp ordusunun geri çekilmesi esnasında meydana gelen tecavüzler neticesinde, "Sırp etnik kimliği" ile yüzlerce bebek doğmuştur. ${ }^{47}$ Diğer bir olumsuz tecrübe de Ruanda'da yaşanan savaş suçudur. 1990 ilâ 1993 yılları arasında Ruanda' da gerçekleşen soykırımda sayıları 250.000 ilâ 500.000 arasında değişen Tutsi kadınına Hutular tarafından tecavüz edilmiştir. ${ }^{48}$ Tutsi kadınlarına karşı gerçekleştirilen tecavüz olayları neticesinde, "nefretin çocukları" olarak adlandırılan toplam 5000 bebek doğmuştur. ${ }^{49}$ Görüldüğü gibi, kadınlar da cinsiyetleri, kimlikleri ya da etnik kökenlerinden dolayı savaşın ve çatışmaların kurbanları olmaktadır. Kadınlara uygulanan şiddetin birçok nedeni olabilmektedir. Öncelikle savaş ve çatışma sırasında ya da sonrasında devlet güçlerinin otoritesinin zayıflamasını firsat bilenler, kadınlara en zayıf oldukları

${ }^{46}$ UNSC (UN Security Council), Security Council Resolution 1325 on Women, Peace and Security, S/RES/1325, 2000.

${ }^{47}$ Megan Bastick, Karin Grimm ve Kunz Rahel, Sexual Violence in Armed Conflict: Global Overview and Implications, Centre for the Democratic Control of Armed Forces, Geneva, 2007, ss. 55, 57, 117; Megan Gerecke, "Explaining Sexual Violence in Conflict Situations", Laura Sjoberg ve Sandra Via, (ed.) Gender, War, and Militarism, Praeger Security International, New York, 2010, s. 139.

48 Nicole Hogg, "Women's Participation in the Rwandan Genocide: Mothers or Monsters?", International Review of the Red Cross, 2010, 877 (92), ss. 69-102; Megan Gerecke, age, s. 57.

${ }^{49}$ Human Rights Watch (HRW), "Shattered Lives: Sexual Violence during the Rwandan Genocide and its Aftermath", Human Rights Watch Women's Rights Project, New York, 1996; Helen Hintjens, "Explaining the 1994 Genocide in Rwanda", The Journal of Modern African Studies, 1999, 37, ss. 241-286; Elizabeth J.Wood, "Sexual Violence During War: Toward an Understanding of Variation", Laura Sjoberg ve Sandra Via (ed.) Gender, War, and Militarism, Praeger Security International, New York, 2010, s. 124. 
anda saldırmakta ve şiddet uygulamaktadır. ${ }^{50}$

Feministler, kadınların ikincil konumu ve ezilmişliğinde hemfikir olsalar da güvenlik alanına yaklaşımlarında farklı görüşlere sahiptirler. Güvenlik çalışmalarına toplumsal cinsiyet ve feminizm açısından ele alan yaklaşımlar; liberal feminizm, feminist duruş yaklaşımı (standpoint feminism) ve post-yapısalcı toplumsal cinsiyet (Poststructural gender approaches) yaklaşımlarıdır. ${ }^{51}$ Liberal feminizmin temel bakış açısı, kadın-erkek ayrımı yapmadan insan olarak eşitlik ve bireyin özerkliği ve özgürlügüdür. Kadınlarla erkeklerin eşitliğini politikada, ekonomide ve toplumsal yaşamda tam anlamıyla eşitlik olarak tanımlamaktadır. Kurama göre, kadınlar ancak onlara yüklenen geleneksel rollerden çıktıkları zaman erkelerle eşitlik şansını yakalayabilir. Örneğin, kadınların eş ve anne olarak doğal olarak kabul edilen rolleri, kadınların toplumdaki eşitsiz konumlarının göstergeleridir. ${ }^{52}$ Liberal feminizme göre, "oy hakk1, eşit eğitim, eşit iş, eşit ücret" kadınlar ve erkekler arasında eşitliğin sağlanması için gereklidir. ${ }^{53}$ Liberal feminizm, cinsiyet eşitliği ve güvenlik çalışmaları arasında ilişki kurarak kadınların da, tıpkı erkekler gibi, bu alanda görünür olmaları gerektiğini savunmuştur. Güvenlik alanını liberal feminizm açısından değerlendiren Enloe'a göre, kadınların güvenlik alanında daha fazla görünür olmaları gerekmektedir. Yazara göre, erkeklerin kontrolünde olan uluslararası güvenlik aslında ataerkil

\footnotetext{
${ }^{50}$ Christopher K. Butler, Tali Gluch ve Neil J.Mitchell, "Security Forces and Sexual Violence: A Cross National Analysis of a Principal-Agent Argument", Journal of Peace Research, 2007, 44 (6), ss. 669-687; Carolyn Fowler, Julie Dugan ve Paul Bolton, "Assessing the Opportunity for Sexual Violence against Women and Children in Refugee Camps", The Journal of Humanitarian Assistance, Feinstein International Center at Tufts University, 2000, ss. 1-7.

${ }^{51}$ Columba Peoples ve Vaughan-Williams, Nick, age, s. 36.

52 Liesbet Van Zoonen, "Medyada Feminist Yaklaşımlar", Süleyman İrvan (ed.) Medya, Kültür, Siyaset, Alp Yayınevi, Ankara, 2002, s. 473.

53 Mutlu Binark, "İletişim Araştırmalarında Kadın Müdahalesi”, A. ̈̈. İletişsim Fakültesi Yıllık, 1992, ss. 63-64.
}

\section{9}

Güvenlik Stratejileri

Y11: 14

Say1: 27 


\section{0}

Güvenlik

Stratejileri

Y11: 14

Say1: 27

düzeni korumaktadır. ${ }^{54}$

Güvenlik ve toplumsal cinsiyet ile ilgili, liberal feminizme alternatif bir bakış açısını feminist duruş yaklaşımı getirmektedir. Güvenlik konusuna feminist duruş yaklaşımı açısından bakan Tickner'a göre, güvenlik alanını kuramlaştırmak için kadınların bakış açıları ve deneyimleri son derece önemlidir. ${ }^{55}$ Bunun için ampirik araştırmaların yapılmas1 gerekmektedir. Yazara göre, uluslararas1 alan maskülen özellikler olan güç, iktidar ve özerk ile ilişkilendirilmektedir. Bunun en büyük sebebi, savaşlar ve maskülen yapının ulus-devlet ile bağlantılı olmasıdır. Oysa uluslararası yapının maskülen özelliklerinin tam tersine, aile içi politikalar dişilik özellikleriyle tanımlanmaktadır. Uluslararası güvenliğin toplumsal cinsiyet politikaları, erkeğin ulusal sınırlar içinde korunmaya muhtaç kadınların ve çocukların güvenliğini temin altına almakla ilgilidir. Kadınların güvenlikle ilgili ilişkisi sadece ev içi işleri yerine getirmekle ve sosyal hayatın toplumsal cinsiyet işlevlerini yapmakla sınırlı gözükmektedir. Tarihsel olarak da kadınların iş gücü çocuk yetiştirmek, öğretmenlik, ev içi işler ya da hemşirelik olarak algilanmaktaydı. Oysa ki üzerinde durulması gereken nokta, birbirinden farklı insan güvensizliğinin (human insecurity) nasıl toplumsal cinsiyetleştiğidir. Yazara göre, toplumsal cinsiyet eşitsizliğinin üstesinden gelmek için öncelikle kadın ve erkeklerin bakış açılarının ve deneyimlerinin birbirinden farklı olduğunu kabul etmek gerekmektedir.

Post-yapısalcı toplumsal cinsiyet yaklaşımına göre ise, kadınlara özel bir varoluşsal yap1 verilmediğini ve toplumsal cinsiyetin sadece toplumsal olarak üretilecek kadar basit olmadığını belirtmektedir. Kuram, kadınların söylemsel olarak da inşa edildiğini iddia etmektedir. Ayrıca, toplumsal cinsiyet kimlikleri günlük yaşam pratikleri aracılığıyla da üretilmektedir. Güvenlik çalışmalarında bunun anlamı; birbiriyle içi içe geçmiş hiyerarşik ve tahakküm sistemlerinin içinde güvenliğin ne anlama geldiği ve toplumsal cinsiyet kimlikleri ve ideolojilerinin bu yapısal

${ }^{54}$ Cynthia Enloe, age.

${ }^{55}$ Ann J. Tickner, age. 
güvensizlikleri (structural insecurities) nasıl ürettiği sorusuyla başlamaktadır. Örneğin, "ulusal ve uluslararası güvenlik" her ne kadar güvenliği sağlamak için yapılsa da, aslında hiyerarşik yapıyı üretmektedir. $^{56} \mathrm{Bu}$ hiyerarşik yapı içerisinde toplumsal cinsiyet siyasileşmekte ve anlam kazanmaktadır. Böylesi bir yapılanmada, kadınlar korunmaya muhtaç olarak yansıtmaktadır. Bildiride şu ifadeye yer verilmiştir: ${ }^{57}$

Kadınları ve çocukları savaşın dehşetinden korumak için her türlü çaba gösterilir. Özellikle kadınların ve çocukların bir bölümünü oluşturduğu sivil halka karşı zulüm, işkence, cezalandırma, onur kırıcı muamele ve şiddet gibi muamelelerin yapılması yasaklanmasını sağlamak için gerekli her türlü tedbir alınır.

Diğer bir örnek, 1325 Sayılı BM Kararı'dır. Karar; savaş ve çatışmalarda toplumsal cinsiyet temelli şiddet, barış ve devlet inşası sürecinde alınması gereken tedbirleri kapsamasına rağmen, kadınların diğer kadınlar ya da erkekler üzerindeki tahakkümüne yer vermemektedir. ${ }^{58} \mathrm{Bu}$ durum şu şekilde yer almaktadır. ${ }^{59}$

Kadınların ve kız çocukların çatışma durumlarında korunması, özel gereksinimleri ve kadınların ve çocukların insan hakları hakkında, barış gücü personelinin özel eğitim almalarına dair tavsiyesinin önemini de kabul ederek; silahlı çatışmaların tüm taraflarını, kadınları ve kız çocuklarını

\footnotetext{
${ }^{56}$ Spike Peterson (ed.), Gendered States: Feminist (Re) Vision of International Relations Theory, Boulder, Lyrme Riennar Publishers Inc, London 1992.

${ }^{57}$ BM (Birleşmiş Milletler), Birleşmiş Milletler Olağanüstü Durumlarda ve Silahl Çatışma Halinde Kadınların ve Çocukların Korunmalarına İlişkin Bildiri, 1967, http://www.cocukvemedyahareketi.org/Files/pdf/kararlar_arastirmalar/BM_Cocuk_Haklari _Sozlesmesine_Ek_Protokoller/BM_Acil_Durumlarda_ve_Silahli_Catisma_Halinde_Kadi nlarin_ve_Cocuklarin_Korunmasina_Iliskin.pdf, (Erişim Tarihi: 04.03.2018).

${ }^{58}$ Laura Shepherd, Gender, Violence, and Security: Discourse as Practice, Zed Books, 2008.

${ }^{59}$ UNSC (UN Security Council), Security Council Resolution 1325 on Women, Peace and Security, S/RES/1325, 2000.
} 
132

Güvenlik Stratejileri

Y11: 14

Say1: 27

toplumsal cinsiyete dayalı şiddetten, özellikle tecavüz ve diğer cinsel istismar biçimlerinden ve silahlı çatışma durumlarındaki bütün diğer şiddet biçimlerinden korumaya yönelik özel tedbirler almaya çağırır.

Ancak, kadınlar sadece savaş ve çatışmalarda değil, aynı zamanda zorunlu göç sırasında da şiddet olaylarına maruz kalmaktadır. Son yıllarda gerek ulusal, gerekse uluslararası alanda gündemi en çok meşgul eden mülteci konusu ise Suriyeli mültecilerin durumudur. Suriyeli mülteci kadınlar hem göç sırasında, hem de sonrasında çeşitli şiddet olaylarına maruz kalmıştır. ${ }^{60}$ En sık karşılaştıkları tehdit olayları fiziksel şiddet, finansal olarak sömürülme ve diğer mülteciler ya da güvenlik güçleri ile cinsel ilişkiye girmek için baskıya maruz kalma olarak sıralanmaktadır. ${ }^{61}$ Çatışma ortamında bekâr bir kadının ya da evini tek başına geçindirmek zorunda kalan bir kadının maddi imkânlardan ve bir erkeğin korunmasından yoksun olması, şiddete maruz kalmasında en önemli dezavantajlar olarak belirmektedir. Bu tür şiddet olayları diğer mülteci erkeklerden, insan kaçakçılarından ve sınır güvenliğini sağlayan polislerden gelmektedir. Göç sırasında kadınların korkuları ise tecavüze uğramak, insan kaçakçılarının eline düşmek, çocuklarını ve eşlerini kaybetmek, istem dışı hamilelik ve cinsel yolla bulaşan hastalıklara yakalanmak olarak sıralanmaktadır. ${ }^{62}$

${ }^{60}$ Amnesty International, "Female refugees face physical assault, exploitation and sexual harassment on their journey through Europe", https:/www.amnesty.org/en/latest/news/ 2016/01/female-refugees-face-physical assault-exploitation-and-sexual-harassment-ontheir-journey-through-europe/ (Erişim Tarihi: 12.03.2016); Jane Freedman, "Engendering Security at the Borders of Europe: Women Migrants and the Mediterranean Crisis" Journal of Refugee Studies, 2016, ss. 1-15.

${ }^{61}$ Amnesty International, age.

${ }^{62}$ Jane Freedman, age, ss. 1-15; Jaclynn Robinson, A Phenomenological Exploration of the Gendered Vulnerabilities of Internally Displaced Syrians, LSE Middle East Centre Blog, http://blogs.lse.ac.uk/mec/2018/02/22/a-phenomenological-exploration-of-thegendered-vulnerabilities-of-internally-displaced-syrians/ (Erişim Tarihi: 04.03.2018) 
Cinsel tacizin önüne geçmek için de mülteci kadınlar, ailelerin zoruyla ve küçük yaşta evlendirilmektedir. ${ }^{63}$ Cinsel şiddet olaylarından kaçmak için zorla ve erken yaşta evlendirilen Suriyeli mülteci kadınlar, şiddetin başka bir türü olan toplumsal cinsiyet içerikli şiddete maruz kalmaktadır. Suriyeli mülteci kadınlar, genellikle namus cinayeti ya da dışlanmaktan korktukları için başlarına gelen taciz olayları hakkında konuşmak istememektedir. Sessiz kalmaları sonucu tacizciler cezasız kalmakta ve aynı şeyleri yapmaya devam etmektedir. ${ }^{64}$ Yapılan bir araştırmaya göre, iç savaş sonucu ortaya çıkan göçler sonrasında Suriyeli kadınların evlilik yaşlarının 19-20'den 14-15'e kadar düştüğü görülmektedir. Bunun en önemli iki sebebi, güvensizlik ve kötü yaşam koşuları olarak gösterilmektedir. $\mathrm{Bu}$ anlamda küçük yaşta evlilik, Suriye özelinde bir gelenek ya da töre olmanın ötesinde, yaşanan zorluklara karşı bir çözüm mekanizması haline gelmiş durumdadır. Aynı araştırmada, evlilik kadınlar için bir kurtuluş olduğu kadar aileler için de omuzlarındaki sorumluluğun ve ekonomik yükün hafiflemesi anlamına gelmektedir. Hatta Suriye'de yaşamak zorunda kalan aileler kızlarını komşu ülkelere evlenmeleri için göndermeye çalışmaktadır. ${ }^{65}$ $\mathrm{Bu}$ konuda da daha önce komşu ülkelere giden diğer Suriyeliler, özellikle de akrabaları, yardımcı olmaktadır. Bu durum; Göç Kuramları içerisinde sayılan İlişkiler Kuramını akla getirmektedir. Kurama göre; göç edilen ülkeye yerleşen mülteciler üzerinden oluşan sosyal ve ekonomik ağlar göç sürecinin devamında olumlu ya da olumsuz

\footnotetext{
${ }^{63}$ Richard Spencer, "Nearly half a million pregnant women among displaced and refugee Syrians." The Telegraph, http://www.telegraph.co.uk/news/worldnews/middleeast/ syria/12139358/Nearly-half-amillion-pregnant-women-among-displaced-and-refugeeSyrians.html, (Erişim Tarihi: 03.02.2016).

${ }^{64}$ Patrick Strickland, age; Renate Van der Zee, "Life as a female refugee: You don't know who to trust" Aljazeera, http://www.aljazeera.com/indepth/features/2016/02/life-femalerefugee-don-trust-160210092005932.html, (Erişim Tarihi:15.02.2016).

${ }^{65}$ Z. Cherri, J. Gil Cuesta, J.M.Rodriguez-Llanes, D.Guha-Sapir, "Early Marriage and Barriers to Contraception among Syrian Refugee Women in Lebanon: A Qualitative Study”, Int. J. Environ. Res. Public Health, 2017, 14 (8).
}

Güvenlik Stratejileri

Y1l: 14

Say1: 27 
134

Güvenlik Stratejileri

Y11: 14

Say1: 27

etkilere sahiptir. ${ }^{66}$ Komşu ülkelerdeki akrabalar kadınlar için bir kurtuluş yolu olarak gözükse de, istekleri dışında yapılan bu evlilikler kadınlar üzerinde bir tür psikolojik şiddet sayılmaktadır.

Suriyeli mülteci kadınlar sadece göç sırasında değil, aynı zamanda göç ettikleri ülkelerin mülteci kamplarında da şiddet olaylarına maruz kalmaktadır. Özellikle de Avrupa ülkelerinde yer alan transit mülteci kampları kadınların şiddet olaylarına maruz kalmalarını engellemek için yeterince önlem almamakta ve onları koruyamamaktadır. Bunun en büyük sebeplerinden biri, kamplarda kadınlara yönelik özel tedbirlerin alınmamasıdır. Kadınlar tanımadıkları başka mülteci erkeklerle aynı mekânı paylaşmak zorunda kalmaktadır. Çadırlar, konteynerler, banyo ve tuvaletler gibi yerlerde mahremiyetin olmayışı ve kalabalık ortamlarda hiç tanımadıkları kişilerle aynı yeri paylaşmak, mülteci kadınlar için en büyük stres kaynağ olmaktadır. $^{67} \mathrm{Bu}$ nedenle, tacizden korunmak için mülteci kadınların aldıkları tedbirlerin başında konteynerda uyumak yerine dışarıda uyumayı tercih etmeleri gelmektedir. ${ }^{68}$

Mülteci kadınların mülteci kamplarında güvensiz hissetmelerine neden olan diğer bir nokta da, banyo imkânları olarak karşımıza çıkmaktadır. Kadınlar, erkeklerle aynı banyo ve tuvaletleri kullanmak zorunda kalmaktadır. Bazı mülteci erkekler, kadınları banyoya giderken rahatsız etmektedir. $\mathrm{Bu}$ nedenle kadınlar cinsiyet olarak ayrılmayan ve temizlik açısından hijyenik olmayan tuvaletlere gitmemek için yemek yememekte ve su içmemektedir. Bu da birtakım sağlık problemlerine neden olmaktadır. ${ }^{69}$ Diğer taraftan, kamp dışında yaşayan mülteci kadınları başka bir tehlike beklemektedir. Ev sahipleri

${ }^{66}$ Savaş Çağlayan, "Göç Kuramları, Göç ve Göçmen İlişkisi”, Muğla Üniversitesi Sosyal Bilimler Dergisi, Güz 2017, Sayı 17, s. 85.

${ }^{67}$ UNFPA, Voices from Syria 2018: Assessment Findings of the Humanitarian Needs Overview, 2017, https://hno-syria.org/data/downloads/gbv.pdf, s. 26. (Erişim Tarihi: 04.03.2018).

${ }^{68}$ Women's Refugee Commission, No Safety for Refugee Women on the European Route: Report from the Balkans, Women's Refugee Commission, New York, 2016.

${ }^{69}$ Amnesty International, age. 
de yardım bahanesiyle ya da kira karşılığı birçok Suriyeli mülteci kadını cinsel olarak sömürmek istemektedir. ${ }^{70}$ Görüldüğü gibi, kadınların cinsel yönden sömürülmeleri savaş ve çatışmalardan sonra da başka boyutlarda devam etmektedir.

Anlaşıldığı üzere, sadece medya değil, aynı zamanda sivil toplum Güvenlik Stratejileri

Y11: 14 kuruluşları da Suriyeli mülteci kadınların güvenlikle ilgili tehdit algılarına yer vermiştir. Mülteci kadınların sığındıkları ülkeler gerekli güvenlik tedbirlerini aldıkları zaman kadınların algıladıkları tehdit oranı en aza inecektir. Feministlerin eleştirdiği nokta tam da burada ortaya çıkmaktadır. Feminist yazarlar, tehdit algısının toplumsal cinsiyet boyutlarının yeterince araştırılmadığından bahsetmektedir, ${ }^{71}$ çünkü mülteciler göç sırasında birbirlerinden farklı ve özgül tenkide maruz kalmaktadır. ${ }^{72}$

Suriye'de yaşanan iç savaşla birlikte ortaya çıkan göç dalgası, özellikle Batılı ülkeler tarafindan önemli bir güvenlik sorunu olarak değerlendirilmiştir. 11 Eylül saldırılarıyla birlikte artan terör tehdidi ve bu tehdidin Batılı toplumlar üzerinde yarattığı alg1, ortaya konan politikaların Suriyeli göçmenlerin içinde bulundukları kötü durumdan ziyade, göç ettikleri ülkelerde yaratacakları güvensiz ortam üzerine yoğunlaşmasına neden olmuştur. Bu açıdan bakıldığında; her ne kadar 90'lı yıllarla birlikte "insani güvenlik", "eleştirel güvenlik yaklaşımları" ve "özgürleştirme" gibi farklı söylemler literatürde önem kazanmaya başlasa da, uluslararası ortamda aktörlerin kendilerini koruma odaklı, realist politikalar izlemeye devam ettiği görülmektedir. İzlenen bu politikalar, egemen kültür dışında tutulan ve ötekileştirilmiş toplumların istek ve beklentilerine Batılı ülkelerin mesafeli durmasına sebep

\footnotetext{
${ }^{70}$ UNHCR (United Nations High Commissioner for Refugees), Woman Alone: The fight for survival by Syria's refugee women, Office of the United Nations High Commissioner for Refugees, New York, 2014.

${ }^{71}$ Charlotte Bunch, "A Feminist Human Rights Lens on Human Security", Peace Review, 2004, 16; Marta Young Y. ve K. Jacky Chan, "The Psychological Experience of Refugees: A Gender and Cultural Analysis”, Saba Safdar and Natasza Kosakowska-Berezecka, (ed.), Psychology of Gender through the Lens of Culture, Springer Press, 2015.

${ }^{72}$ Edward Newman, age, s. 16.
} 
136

Güvenlik

Stratejileri

Y11: 14

Say1: 27 olurken, tehdit olarak algılanan toplumların daha da marjinalleşmesine sebep olmaktadır.

Çalışmada ortaya konulduğu gibi, bu toplumlar ve sorunları yüzeysel ve realist bir bakış açısı ile kavranamayacak kadar derin özelliklere sahiptir. Konu toplumsal cinsiyet bakış açısı ile irdelendiğinde, yaşanan iç savaşın ve izlenen normatif politikaların neden olduğu zorunlu göçün kadınlar üzerinde yarattığı olumsuz etkilerin ortaya konmasının bu toplumları ve sorunlarını anlamada önemli bir katk1 sağladığ görülmektedir. Dolayısıyla, kadınların şiddete uğramasını en aza indirebilmek için toplumsal cinsiyet temelli bir bakış açısıyla hareket etmek gerekmektedir. Bu nedenle, uluslararası güvenlik alanı sadece eril bir bakış açısından tanımlanmamalıdır. Feminizmin bu alana taşınması ve toplumsal cinsiyet bakış açısından güvenlik kavramının yeniden tanımlanması gerekmektedir. Daha net belirtmek gerekirse, konunun uzmanları insani güvenlik kavramına eğilerek kadınların, erkelerin ve çocukların bireysel düzeyde tehdit algılarını sorgulamalıdır.

\section{Sonuç}

$\mathrm{Bu}$ çalışmada, iç savaş ve izlenen normatif politikalar sebebiyle zorunlu göçe maruz kalan Suriyeli mülteci kadınların güvenlik kaygıları ile bunların şekillenmesinde en önemli faktör olarak gözlemledikleri ve yaşadıkları tehditler eleştirel bir bakış açısıyla ele alınmıştır. Bu bakış açısının ortaya koyduğu en önemli eleştiri, klasik güvenlik yaklaşımlarının günümüzde ortaya çıkan sorunların tam olarak anlaşılmasında yetersiz kaldığg düşüncesini ortaya koymaktadır. En güncel ve popüler güvenlik sorunlarının başında gelen Suriye İç Savaşı ve bunun yol açtığı göç akımı da klasik ve monolitik bir bakış açısı ile anlaşılamayacak kadar karmaşıktır. Bu noktada; farklı disiplinlerle farklı bakış açılarının kullanımı gerektiren bu olayın önemli katmanlarından birisi olarak göçün öncesi, sırası ve sonrasında ortaya çıkan tehditlerin toplumsal cinsiyet açısından incelenmesinin gerekliliği vurgulanmıştır. Son olarak, Batılı ülkelerin dar bir bakış açısıyla yoğunlaştıkları kendi güvenliklerinin ötesinde, zorunlu göç sırasında mülteci kadınların güvenliğinin sağlanmasında, insani güvenlik açısından uluslararası aktörlerin sorumluluğunun önemine değinilmiştir. 
Değerlendirmeler sonucunda; iç savaş ve zorunlu göçün insanlar üzerinde yarattığı genel tehlikelerin ötesinde Suriyeli mülteci kadınların zorunlu göç öncesinde, sırasında ve sonrasında çok çeşitli cinsel ve toplumsal cinsiyet temelli şiddet olaylarına ve tehditlere maruz kaldıkları görülmektedir. Maruz kaldıkları şiddet olayları ve tehdit algısı, içinde bulundukları ortama göre farklılık göstermektedir. Genel olarak değerlendirildiğinde, savaş ve zorlu yaşam koşullarına ek olarak, Suriyeli mülteci kadınlar tecavüze uğramaktan, çocuklarını ve eşlerini kaybetmekten korkmaktadır. Suriyeli mülteci kadınların göç sırasında ya da sonrasında uğradıkları cinsel ve toplumsal cinsiyet temelli şiddet ile ilgili niceliksel bir araştırmanın olmayışı, çalışmanın kısıtlılığını ortaya koymaktadır. Sosyal baskı, utanç, dışlanma, namus cinayeti ya da zorla evlendirme gibi sebeplerden dolay1, Suriyeli mülteci kadınların başlarına gelen şiddet olayları hakkında konuşmamaları hem niceliksel araştırma yapılmamasına, hem de suçluların cezasız kalmasina neden olmaktadır. ${ }^{73}$ Her ne kadar bu konuda yapilan çalışmalar olsa da; bunlar geniş bir bakış açısı ile durumu ortaya koymanın uzağında kalmaktadır. Diğer taraftan, farklı ülkelerde farklı uygulamalara muhatap kalan mültecilerin büyük kısmının devlet kontrolündeki kamplarda misafir edilmeleri, yapılan nitel araştırmalarda önemli bir kısıt oluşturmaktadır.

Göç sırasında toplumsal cinsiyet rolleri de değişmektedir. Eşlerini çatışmalarda kaybeden kadınlar ailenin reisi konumuna gelmektedir. Hem kadın olarak, hem de ailenin reisi rollerinden dolayı omuzlarında iki kat daha fazla yük taşımaktadırlar. Bu anlamda bir erkeğin korumasını ve vesayetini kaybetmiş olma, kadınların göç ve iç savaş süresince

\footnotetext{
${ }^{73}$ UNHCR (United Nations High Commissioner for Refugees), Woman Alone: The fight for survival by Syria's refugee women, Office of the United Nations High Commissioner for Refugees, New York, 2014; Emma MacTavish, Barriers of Reporting Sexual Violence in Syrian Refugee Camps, A Thesis Submitted to the Faculty of Social and Applied Sciences in Partial Fulfillment of the Requirements for the Degree of Master of Arts In Human Security and Peacebuilding, Royal Roads University Victoria, British Columbia, Canada, 2016.
} 
138

Güvenlik

Stratejileri

Y11: 14

Say1: 27 yaşayabilecekleri en büyük dezavantaj olarak görülmektedir. Suriyeli mülteci kadınların söylemlerinde de anlaşıldığı gibi, başlarında baba, eş, erkek kardeş ya da akraba bulunmayan kadınlar daha fazla tacize ve tecavüze uğramaktadır. Hatta mülteci kadınlara yardım maksadıyla kamplarda bulunan yardım görevlileri dâhil bu şiddet türünün birer faili olabilmekte ve bu durum önemli bir güvenlik sorunu olarak karşımıza çıkmaktadır. Bu nedenle, zorunlu göç, tüm boyutları ile anlaşılarak ortaya çıkan sorunlara çözümler üretebilmek adına toplumsal cinsiyet ve insani güvenlik bağlamında da ele alınmalıdır. Her bir mülteci kadının bireysel olarak değerlendirilmesi ve tehdit karşısında korunması gerekliliği insani güvenlik kavramını daha da anlamlı kılmaktadır.

Toplumsal cinsiyet bakış açısına sahip yazarların eleştirdiği en önemli nokta, uluslararası güvenlik alanının sadece eril bir bakış açısıyla yönetiliyor olmasıdır. Bu bakış açısında, kadınlar güvenlik alanında karar verici değil de, daha çok mağdur olarak tanımlanmaktadır. Uluslararası aktörler tarafından kadınların mağdur olmadan önceki tehdit algıları konusunda çok fazla araştırma yapılmamaktadır. Feminizmin bu alana taşınması ve toplumsal cinsiyet bakış açısından güvenlik kavramının yeniden tanımlanması büyük önem arz etmektedir. Bu şekilde, karşılaşılan sorunların ve ötekileştirilen bu toplumların daha iyi anlaşılabilmesi ve sürdürülebilir çözümler üretilmesi imkânlı kılınabilecektir.

\section{Summary}

There are many reasons, such as war, natural disaster, famine, or unemployment why people migrate to other countries. When considered from the point of Syria, it is seen that the reason that affects the migration of people in masses is the civil war in the country. This forced migration has resulted in the emergence of refugees. The civil war in Syria has displaced millions of Syrians from their country. It is considered that 11 million Syrians have fled their homes since the outbreak of the civil war in March 2011. According to the official reports, 6.5 million Syrians have been displaced inside the country; 4.8 million Syrians have fled to neighboring countries such as Turkey, Lebanon, Jordan, and Iraq. In European countries, the number of Syrian refugees has 
reached $1,120,432$. The majority of these refugees have claimed asylum in neighboring or European countries. The migration of millions of Syrians to both European countries and border states has kept refugee Güvenlik influx on the agenda of international actors.

Stratejileri

On the other side, insecure environment of forced migration affects women, men, and child refugees differently. Hence, this study shows the aspects of the "threat" faced by Syrian women refugees during and after forced migration in the context of human security. Protection risks for Syrian refugee women are present in every stage of forced migration; because the types of sexual and gender-based violence to which Syrian refugee women are subjected vary according to the regions. All these security threats also affect the lives of refugee women in a negative way. This perspective brings us closer to the concept of human security. Human security is closely related to the concept of forced migration. The threat perception of refugees escaping from the war, conflict, famine or socioeconomic conditions of the country must be assessed within the concept of human security. Syrian refugee women face different threats in the countries where they seek asylum. For this reason, it is necessary to conduct a gender-based survey to understand the perception of threat of refugee women at the individual level and to take necessary measures. In this study, the security concerns of Syrian refugee women have been considered. Results show that Syrian refugee women are exposed to various sexual and gender based violence during forced migration. They are also afraid of being raped, losing their children and husbands during migration. Gender roles change during migration. Women who lose their husband take the position of reign of the family. This situation increases the burden on their shoulders. Syrian refugee women who do not have a husband, father, brother or other male relative are more expose the violence. Unfortunately, they are reluctant to talk about violent incidents that they face, due to the social pressure, shame, exclusion, honor killings or forced marriage. This causes criminals to remain unpunished. Besides, the lack of a quantitative research on sexual and gender-based violence reveals the limitations of studying. Consequently, every refugee women need to be assessed individually, and they must be protected against threats that makes the concept of human security even more meaningful. 


\section{0}

Güvenlik

Stratejileri

Y11: 14

Say1: 27

\section{Kaynakça}

Kitaplar

BASTICK, Megan, Grimm Karin ve Rahel Kunz, Sexual Violence in Armed Conflict: Global Overview and Implications, Centre for the Democratic Control of Armed Forces, Geneva, 2007.

BOOTH, Ken, Theory of World Security, Cambridge University Press, Cambridge, 2007.

BUZAN, Barry, People, States and Fear: The National Security Problem in International Relations, Harvester Books, Chapel Hill, University of North Carolina Press, Brighton, 1983.

BUZAN, Barry, Ole Wæver ve Jaap de Wilde, Security: A New Framework for Analysis, Lynne Rienner Publishers, Boulder, 1998.

DOUGHERTY, James E. ve Robert L. Pfaltzgraff, Contending Theories of International Relations, Longman, New York, 2001.

ENLOE, Cynthia, Bananas, Beaches and Bases: Making Feminist Sense of International Politics, University of California Press, Berkeley CA 1989.

KATZENSTEIN, Peter (ed.), The Culture of National Security: Norms and Identity in World Politics, Columbia University Press, New York, 1996.

KRAUSE, Keith ve Michael Williams, Critical Security Studies: Concepts and Cases, UCL Press, London, 1997.

PEOPLES, Columba ve Nick Vaughan-Williams, Critical Security Studies, Routledge, New York, 2010.

PETERSON, Spike (ed), Gendered States: Feminist (Re) Vision of International Relations Theory, Lyrme Riennar Publishers Inc, Boulder, London, 1992.

POKU, Nana. K. ve David Graham, Migration, Globalisation and Human Security Routledge, London, 2000.

SHEPHERD, Laura, Gender, Violence, and Security: Discourse as Practice, Zed Books, 2008.

TERRIFF, Terry, Security Studies Today, Polity Press, Cambridge, 1999. TICKNER, Ann J., Gender in International Relations: Feminist Perspectives on Achieving International Security, Colombia University Press, New York, 1992. 
WALTZ, Kenneth, Theory of International Politics, Addison Wesley, Reading, MA, 1979.

WALLERSTEIN, Immanuel, The Modern World-System: Capitalist Güvenlik Agriculture and the Origins of European World-Economy in the Stratejileri Sixteenth Century, New York: Academic Press, 1974.

Makaleler ve Kitap Bölümleri

ALKER Hayward, "Emancipation in the critical security studies project", C. Hacke, G.K. Kindermann and K.M. Schellhorn, (ed.), The Heritage, Challenge, and Future of Realism, Bonn University Press, Göttingen, 2005.

BALDWIN, A David, "The Concept of Security", Review of International Studies, 1997, no. 23, 5-26.

BARKAWI, Tarak ve Mark Laffey, "The Postcolonial Moment in Security Studies", Review of International Studies, 2006, 32 (2), 329-352.

BILGIN, P1nar, "Critical Theory, Security Studies: An Introduction," Paul D. Williams (ed.), Security Studies, New York, Routledge, 2008, 89-102.

BINARK, F. Mutlu, "İletişim Araştırmalarında Kadın Müdahalesi”, A. ̈. İletişim Fakültesi Yıllık, 1992, 61-78.

BOOTH, Ken, "Security and Emancipation", Review of International Studies, 1991, 17, 313-326.

BUNCH, Charlotte, "A Feminist Human Rights Lens on Human Security”, Peace Review, 2004, 16, 29-34.

BUTLER, Christopher K., Tali Gluch ve Neil J. Mitchell, "Security Forces and Sexual Violence: A Cross-National Analysis of a Principal-Agent Argument", Journal of Peace Research, 2007, 44 (6), 669-687.

CHERRI, Z.; Gil Cuesta, J.; Rodriguez-Llanes, J.M.; Guha-Sapir, D. "Early Marriage and Barriers to Contraception among Syrian Refugee Women in Lebanon: A Qualitative Study", Int. J. Environ. Res. Public Health, 2017, 14 (8).

ÇAĞLAYAN, "Savaş, Göç Kuramları, Göç ve Göçmen İlişkisi”, Muğla Üniversitesi Sosyal Bilimler Dergisi, Güz 2017, Say1 17, 67-91.

ELMAN, Colin, "Realism", Paul D. Williams (ed.), Security Studies, Routledge, New York, 2008, 15-26. 

Women Migrants and the Mediterranean Crisis", Journal of Refugee Studies, 2016, 1-15.

Opportunity for Sexual Violence against Women and Children in Refugee Camps", The Journal of Humanitarian Assistance, Feinstein International Center at Tufts University, 2007, 1-7.

GERECKE, Megan, "Explaining Sexual Violence in Conflict Situations", Laura Sjoberg ve Sandra Via (eds.), Gender, War, and Militarism, Praeger Security International, New York, 2010, 137-154.

HINTJENS, Helen, "Explaining the 1994 Genocide in Rwanda", The Journal of Modern African Studies, 1999, 37, 241-286.

HOGG, Nicole, "Women's Participation in The Rwandan Genocide: Mothers or Monsters?", International Review of the Red Cross, 2010, 877, 69-102.

KENNEDY, Caroline, "Gender and Security", Alan Collins (ed.), Contemporary Security Studies, Oxford University Press, Oxford, 2013, 118-130.

KERR, Pauline, "Human Security", Alan Collins (ed.), Contemporary Security Studies, Oxford University Press, Oxford, 2013, 104-117.

LEE, Everett S., “A Theory of Migration”, Demography, 1966, Vol. 3, No. 1, 47-57.

MCDONALD, Matt, 2008, "Constructivism", Paul D. Williams (ed.), Security Studies: An Introduction, Routledge, New York, 2008, 59-72.

MCDONALD, Matt, "Human security and the construction of security", Global Society, 2002, 16(3), 277-295.

NEWMAN, Edward, "International Security, and Human Vulnerability: Introduction and Survey", Edward Newman and Joanne van Selm (eds.), Refugees and Forced Displacement: International Security, Human Vulnerability, and The State, United Nations University Press, New York, 2003, 3-31.

NYE, Joseph, "The Changing Nature of World Power", Political Science Quarterly, 1990, 105/2: 177-192.

VAN Zoonen, L., "Medyada Feminist Yaklaşımlar", Süleyman İrvan (ed.), Medya, Kültür, Siyaset, Alp Yayınevi, Ankara, 2002, 467-514. 
WALTZ, Kenneth, "Political Structures", Robert O. Keohane (ed.), Neorealism and its Critics, Colombia University Press, New York, 1986. WÆVER, Ole, "Securitization and Desecuritization", Ronnie D. Lipschutz (ed.), On Security, Columbia UP, New York, 1995, 46-86. WOOD, J. Elizabeth, "Sexual Violence During War: Toward an Understanding of Variation", Laura Sjoberg ve Sandra Via (eds.), Gender, War, and Militarism, Praeger Security International, New York, 2010, 124-137.

YOUNG Y. Marta and K. Jacky Chan, "The Psychological Experience of Refugees: A Gender and Cultural Analysis", Saba Safdar and Natasza Kosakowska-Berezecka (eds.), Psychology of Gender through the Lens of Culture, Springer Press, 2015, 17-36., doi: 10.1007/978-3-319-14005-6.

\section{İnternet Siteleri}

Amnesty International İnternet Sitesi, "Female refugees face physical assault, exploitation and sexual harassment on their journey through Europe", https://www.amnesty.org/en/latest/news/2016/01/femalerefugees-face-physical-assault-exploitation-and-sexual-harassment-ontheir-journey-through-europe/ (Erişim Tarihi: 12.03.2016).

ROBINSON, Jaclynn, A Phenomenological Exploration of the Gendered Vulnerabilities of Internally Displaced Syrians, LSE Middle East Centre Blog, $\quad$ http://blogs.lse.ac.uk/mec/2018/02/22/a-phenomenologicalexploration-of-the-gendered-vulnerabilities-of-internally-displacedsyrians/ (Erişim Tarihi: 04.03.2018)

\section{Raporlar}

BM (Birleşmiş Milletler), Birleşmiş Milletler Olağanüstü Durumlarda Ve Silahlı Çatışma Halinde Kadınların Ve Çocukların Korunmalarına İlişkin Bildiri, Birleşmiş Milletler, 1967, http://www.cocukvemedya hareketi.org/Files/pdf/kararlar_arastirmalar/ BM_Cocuk_Haklari_Sozlesmesine_Ek_Protokoller/BM_Acil_Duruml arda_ve_Silahli_Catisma_Halinde_Kadinlarin_ve_Cocuklarin_Korun masina Iliskin.pdf (Erişim Tarihi: 04.03.2018)

BMMYK (Birleşmiş Milletler Mülteciler Yüksek Komiserliği), Mültecilerin Hukuki Statüsüne Illişkin Sözleşme, Birleşmiş Milletler Mülteciler Yüksek Komiserliği, 2016. 

Human Rights Watch (HRW), "Shattered Lives: Sexual Violence during the Rwandan Genocide and its Aftermath", Human Rights Watch Women's Rights Project, New York, 1996.

Y11: 14 OCHA (United Nations Office for the Coordination of Humanitarian Affairs), "About the Crisis.", http://www.unocha.org/syrian-arabrepublic/syria-country-profile/about-crisis, (Erişim Tarihi: 17.06.2016).

UNFPA (The United Nations Population Fund), Voices from Syria 2018: Assesment Findings of the Humanitarian Needs Overview, 2017, https://hno-syria.org/data/downloads/gbv.pdf.

UNHCR (United Nations High Commissioner for Refugees), Convention and Protocol Relating to the Statue of Refugees. Office of the United Nations High Commissioner for Refugees, 1951 and 1967.

UNHDP (United Nations Human Development Programme), United Nations Human Development Report, New York: Oxford University Press, 1994.

UNSC (UN Security Council), Security Council Resolution 1325 on Women, Peace and Security, S/RES/1325, 2000.

UNHCR (United Nations High Commissioner for Refugees), Sexual and Gender-Based Violence against Refugees, Returnees and Internally Displaced Persons, The Office of the United Nations High Commissioner for Refugees, Geneva, 2003.

United Nations Report of the Commission on Human Security, Human Security Now: Protecting and Empowering People, UN, New York, 2003.

UNHCR (United Nations High Commissioner for Refugees), Woman Alone: The Fight for Survival by Syria's Refugee Women, Office of the United Nations High Commissioner for Refugees. New York, 2014.

UNHCR (United Nations High Commissioner for Refugees), Worldwide Displacement Hits all-time High as War and Persecution Increase, Office of the United Nations High Commissioner for Refugees, New York, 2015.

UNHCR (United Nations High Commissioner for Refugees), Syria Regional Refugee Response, Office of the United Nations High Commissioner for Refugees, New York, 2016. 
Women's Refugee Commission, No Safety for Refugee Women on Commission, New York, 2016.

\section{Tezler}

MACTAVISH, Emma, "Barriers of Reporting Sexual Violence in Syrian Refugee Camps", A Thesis Submitted to the Faculty of Social and Applied Sciences in Partial Fulfillment of the Requirements for the Degree of Master of Arts In Human Security and Peacebuilding, British Columbia, Canada: Royal Roads University Victoria, 2016.

\section{Gazeteler}

ENSOR, Josie, "Women in Syria 'forced to exchange sexual favours' for UN aid", The Telegraph, https://www.telegraph.co.uk/news/2018/02/27/ women-syria-forced-exchange-sexual-favours-un-aid/ (Erişim Tarihi: 24.03.2018.)

SPENCER, Richard, "Nearly half a million pregnant women among displaced and refugee Syrians." The Telegraph, http://www.telegraph. co.uk/news/worldnews/middleeast/syria/12139358/Nearly-half-amillionpregnant-women-among-displaced-and-refugee-Syrians.html (Erişim Tarihi: 03.02.2016).

STRICKLAND, Patrick, "Refugee crisis: Hungary sends more troops to border." Aljazeera, http://www.aljazeera.com/news/2016/03/refugeecrisis-hungary-sends-troops-border-160309134453267.html (Erişim Tarihi: 10.03.2016).

VAN der Zee, Renate, "Life as a female refugee: You don't know who to trust." Aljazeera, http://www.aljazeera.com/indepth/features/2016/02/lifefemale-refugee-don-trust-160210092005932.html, (Erişim Tarihi: 15.02.2016).

Güvenlik Stratejileri

Y11: 14

Sayı: 27 
